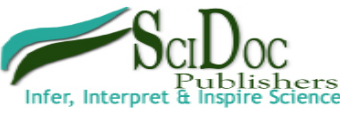

International Journal of Stem Cell Research and Transplantation (1JST)

ISSN: 2328-3548

\title{
Epigenetic Regulation of Retinal Stem Cells
}

Editorial

Mimura $\mathrm{T}^{1^{*}}$, Noma $\mathrm{H}^{2}$, Funatsu $\mathrm{H}^{3}$

${ }^{1 *}$ Department of Ophthalmology, Tokyo Women's Medical University Medical Center East, Tokyo, Japan.

${ }^{2}$ Department of Ophthalmology,Hachioji Medical Center Tokyo Medical University, Tokyo, Japan.

${ }^{3}$ Department of Ophthalmology, Yachiyo Medical Center, Tokyo Women's Medical University, Chiba, Japan.

\section{*Corresponding Author:}

Tatsuya Mimura,

Department of Ophthalmology,

Tokyo Women's Medical University Medical Center East,

]2-1-10 Nishiogu,Arakawa-ku,

Tokyo, 116-8567 Japan.

Tel: +81-3-3810-1111 (Ex7765); Fax: +81-3-3894-0282

E-mail: mimurat-tky@umin.ac.jp

Accepted: March 01, 2013

Published: March 13, 2013

Citation: Mimura T, Noma H, Funatsu H. (2013). Epigenetic Regulation of Retinal Stem Cells, Int J Stem Cell Res Transplant, 01(2e), 01-02. doi: http://dx.doi.org/10.19070/2328-3548-130002e

Copyright: Mimura $\mathbf{T}^{\circ}$ 2013. This is an open-access article distributed under the terms of the Creative Commons Attribution License, which permits unrestricted use, distribution and reproduction in any medium, provided the original author and source are credited.

Epigenetics is defined as the investigation of stably heritable changes of gene expressionthat occur without alteration ofthe DNA sequence itself [1-3]. Epigenetic gene regulation usually involves DNA methylation and/or modification of histones [4]. In mammalian cells, DNA methylation mainly occurs at the fifth carbon of the cytosine residuein a 5'-CG-3' (CpG) dinucleotide and its occurrence is inversely correlated with the GC content and CpG density [5,6]. Epigenetic regulation has a role in many biological processes, including gene transcription, imprinting, and transposon activity in embryonic stem cells, germ cells, somatic cells, and tumor cells [7-9]. Histone modification represents an additional epigenetic mechanism that regulates gene expression, genomic imprinting, and X chromatin remodeling synergeticallyalong with DNA methylation [10,11].

Stem cells are able to self-renew and proliferate within the niche, where they are maintained in an undifferentiated and quiescent state by interactions with the surrounding matrix and nichecells that involve integrins and cadherins, respectively. The niche and its components protect stem cells from stress, such as accumulation of free radicals and reactive oxygen species (ROS). Therefore, keeping ROS level low is linked to the maintenance of stem cellsin an immature state. Aging of stem cells is mainly induced by telomere shortening, oxidative stress, and epigenetic changes of the genomeas in other cell types. An increase of ROS inducesup-regulation of p16INK4a and p19ARF [12]. Polycomb group (PcG) genesplay a key role in the epigenetic regulation of stem cells. Epigenetic regulation of stem cell self-renewal/proliferation and commitmen is controlled by PcG protein at amajor cell cycle checkpoint [13], through which the activated p19Arf-p53-p21retinoblastoma protein $(\mathrm{Rb})$ and $\mathrm{p} 16 \operatorname{Ink} 4 \mathrm{a}-\mathrm{Rb}$ pathways mediate heterochromatin formation and silencing of E2F target genes during cellular senescence[14]. Epigenetic regulation is also important for the maintenance of retinal stem cells and for normal retinal development [15].

Retinal diseases (mainly age-related macular dystrophy and the hereditary retinal dystrophies) are a major cause of blindness worldwide. Lifestyle-related diseases, such as hypertension, hyperlipidemia, diabetesmellitus, and obesity, are alsoare risk factors for retinal diseases[16]. Since the main underlying problem in retinal degeneration is the loss of retinal neural cells, treatment strategies aimed at regenerating neural cells and retinal pigment epitheliumcells have been examined as potential therapeutic modalities. Transplantation studies using immature cells derived from the neural retina have demonstrated that transplanted neuronal progenitor cells are integrated into the developing retina and acquire the morphological features of retinal photoreceptors including rhodopsin [17]. Recently, transplantation of induced pluripotent stem cells (iPS) into the subretinal space has also been investigated in animal models [18-21], and these studies have demonstrated that transplanted iPS are integrated into all major retinal cell layers and express photoreceptor markers [21]. Since the risk of adverse effects due to the viral vector is not negligible, further investigation is required to establish a virus-free protocol for the transplantation of iPS. Identification of highly demethylated stem cells by application of epigenetic profiling could offer a higher potential for the therapeutic application of stem cells for retinal repair in the future.

\section{References}

[1]. Rakyan VK, Blewitt ME, Druker R, Preis JI, Whitelaw E (2002) Metastable epialleles in mammals. Trends Genet 18:348-351.

[2]. Rakyan VK, Chong S, Champ ME, Cuthbert PC, Morgan HD,et al. (2003) Transgenerational inheritance of epigenetic states at the murine $\operatorname{Axin}(\mathrm{Fu})$ allele occurs after maternal and paternal transmission. ProcNat1AcadSci USA 100:2538-2543.

[3]. Anway MD, Cupp AS, Uzumcu M, Skinner MK (2005) Epigenetic transgenerational actions of endocrine disruptors and male fertility. Science 308:1466-1469

[4]. Wolffe AP, Matzke MA(1999) Epigenetics: regulation through repression. Science 286:481-486

[5]. BirdA(2002)DNAmethylationpatternsandepigeneticmemory. GenesDev 16: 6-21.

[6]. Illingworth RS, Bird AP (2009)CpG islands--'a rough guide'.FEBS Lett583:1713-1720.

[7]. Arányi T, Páldi A (2006)The constant variation: DNA methylation changes during preimplantation development.FEBS Lett 580:6521-6526.

[8]. Farthing CR, Ficz G, Ng RK, Chan CF, Andrews S, et al. (2008) Global mapping of DNA methylation in mouse promoters reveals epigenetic reprogramming of pluripotency genes. PLoS Genet4:e1000116.

[9]. Xie H, Wang M, BonaldoMde F, Smith C, Rajaram V, et al. (2009) Highthroughput sequence-based epigenomic analysis of Alu repeats in human cerebellum.Nucleic Acids Res37:4331-4340.

[10]. KatoS,YokoyamaA,FujikiR (2011)Nuclearreceptorcoregulatorsmergetranscriptionalcoregulation withepigeneticregulation. TrendsBiochemSci 36: 272-281. 
[11]. LohYH,YangL,YangJC,LiH,CollinsJJ,et al. (2011) Genomic approachestodeconstructpluripotency. AnnuRevGenomicsHumGenet 12: 165-185.

[12]. Ito K, Hirao A, Arai F, Matsuoka S, Takubo K, et al. (2004) Regulation of oxidative stress by ATM is required for selfrenewal of haematopoietic stem cells.Nature 431:997-1002.

[13]. Kim WY, Sharpless NE (2006) The regulation of INK4/ ARF in cancer and aging.Cell127:265-275.

[14]. Pollina EA, Brunet A(2011) Epigenetic regulation of aging stem cells. Oncogene30:3105-3126.

[15]. Chatoo W, Abdouh M, Duparc RH, Bernier G (2010) Bmil distinguishes immature retinal progenitor/stem cells from the main progenitor cell population and is required for normal retinal development.Stem Cells28:1412-1423.

[16]. Funatsu H, Yamashita H, Sakata K, Noma H, Mimura T, et al. (2005) Vitreous levels of vascular endothelial growth factor and intercellular adhesion molecule 1 are related to diabetic macular edema.Ophthalmology112:806-816.

[17]. Takahashi M, Palmer TD, Takahashi J, Gage FH (1998) Widespreadintegration and survival of adult-derived neural progenitor cells inthe developing optic retina. Mol Cell Neurosci 12:340-348.

[18]. Buchholz DE, Hikita ST, Rowland TJ, Friedrich AM, Hinman CR, et al. (2009) Derivation of functional retinal pigmented epithelium from induced pluripotent stem cells.Stem Cells27:2427-2434

[19]. Comyn O, Lee E, MacLaren RE (2010)Induced pluripotent stem cell therapies for retinal disease.CurrOpinNeurol23:4-9.

[20]. Osakada F, Hirami Y, Takahashi M (2010)Stem cell biology and cell transplantation therapy in the retina.Biotechnol Genet Eng Rev 26:297-334.

[21]. Lamba DA, McUsic A, Hirata RK, Wang PR, Russell D, et al. (2010) Generation,purification and transplantation of photoreceptors derived from human induced pluripotent stem cells. PLoS One 5:e8763. 